\title{
Hubungan antara Dukungan Keluarga dengan Kepatuhan Diet pada Penderita Diabetes Mellitus Tipe 2
}

\author{
Argi Virgona Bangun ${ }^{1}$, Galih Jatnika ${ }^{2}$, Herlina $^{3}$ \\ ${ }^{1,2,3}$ STIKes Jendral Achmad Yani Cimahi, Indonesia \\ Corresponding Author : argie.virgona@gmail.com
}

\begin{abstract}
Abstrak
Diabetes Mellitus (DM) adalah gangguan di mana kadar gula (glukosa) abnormal tinggi karena tubuh tidak memproduksi cukup insulin untuk memenuhi kebutuhannya. Mayoritas orang dengan diabetes memiliki diabetes tipe 2. Jenis diabetes ini sebagian besar merupakan hasil dari kelebihan berat badan dan aktivitas fisik. Agar berhasil mengelola diabetes mereka, pasien harus mematuhi rejimen pengobatan yang meliputi pembatasan diet, tujuan aktivitas fisik yang teratur, mempertahankan berat badan yang normal dan pemantauan kadar glukosa secara mandiri. Salah satu faktor yang mempengaruhi kemampuan pasien untuk patuh dengan benar adalah dukungan keluarga. Tujuan dari penelitian ini adalah untuk menguji hubungan antara dukungan keluarga dan kepatuhan diet pada pasien diabetes di wilayah kerja pusat kesehatan masyarakat di Cimahi Utara Jawa Barat. Penelitian deskriptif cross-sectional dilakukan di Puskesmas Cimahi Utara. Teknik pengambilan sampel yang digunakan dalam penelitian ini adalah total sampling sebanyak 48 responden. Data diambil dengan menggunakan kuesioner terjemahan dari versi Bahasa Inggris yakni Hensarling Diabetes Family Support Scale (HDFSS) dan Perceived Dietary Adherence Quetioneraire (PDAQ). Kedua kuesioner ini telah diuji validitas dan reliabilitasnya. Hasil penelitian menunjukkan bahwa sebanyak 56,3\% responden menganut program diet. Selain itu, 47,9\% responden memiliki dukungan keluarga yang layak. Dengan menggunakan uji Chi-square, hasilnya mengungkapkan, ada hubungan yang bermakna antara dukungan keluarga dan kepatuhan $\operatorname{diet}(p=0,038 ; p>\alpha)$. Dapat disimpulkan bahwa dukungan keluarga merupakan faktor penting dalam kepatuhan pasien DM terhadap program diet. Oleh karena itu, melibatkan anggota keluarga, terutama pasangannya, dalam perilaku perawatan diri seperti menyiapkan makanan dapat menjadi sangat penting dalam memberikan perawatan kesehatan dan mencegah komplikasi pada pasien dengan diabetes.
\end{abstract}

Kata kunci: diabetes mellitus, dukungan keluarga, kepatuhan diet

\begin{abstract}
Diabetes mellitus (DM) is a disorder in which blood sugar (glucose) levels are abnormally high because the body does not produce enough insulin to meet its needs. The majority of people with diabetes have type 2 diabetes. This type of diabetes is largely the result of excess body weight and physical inactivity. In order to manage their diabetes successfully, patients must adhere to treatment regimens that include dietary restrictions, regular physical activity goals, maintaining a normal body weight and self-monitoring of glucose levels. One of factors affect patient ability to adhere properly is family support. The purpose of this research was to examine the correlation between family support and diet adherence in patients with diabetes in working area of public health center in North Cimahi West Java. A descriptive cross-sectional study was conducted at North Cimahi Public Health Center. The sampling technique used in this study was total sampling. 48 respondents were assessed using the Bahasa version of Hensarling Diabetes Family Support Scale (HDFSS), and Perceived Dietary Adherence questionnaire (PDAQ). The two questionnaires have been tested for validity and reliability. The results showed that as many as 56,3\% of the respondents adhered to the diet program. Additionally, 47,9\% of respondents had proper family support. By using Chisquare test, the results revealed, there was a meaningful relationship between family support and dietary adherence $(p=0.038 ; p>\alpha)$. It can be concluded that family support is an important factor in DM patients' adherence to a dietary program. Therefore, getting the family members, especially the spouse, involved in self-care behavior such as preparing the meal can be of significant importance in providing health care and prevent complications to patients with diabetes.
\end{abstract}

Keywords: diabetes mellitus, family support, dietary compliance 
Jurnal IImu Keperawatan Medikal Bedah 3 (1), Mei 2020, 1-76

ISSN 2338-2058 (print), ISSN 2621-2986 (online)

\section{PENDAHULUAN}

Diabetes mellitus (DM) merupakan penyakit menahun dimana kadar ggula darah (glukosa) menimbun dan melebihi nilai normal. Tubuh memerlukan bahan untuk membentuk sel baru dan mengganti sel yang rusak, juga memerlukan energi agal sel tubuh dapat berfungsi baik, energi berasal dari bahan makanan yangkita konsumsi sehari- hari (Fransisca, 2012).

Sekitar $90-95 \%$ pasien menderita DM tipe 2. DM tipe 2 yaitu pankreas masih bisa membuat insulin tetapi dengan kualitas insulin yang buruk dan tidak dapat berfungsi dengan baik. Pada DM tipe 2 ini, penderita diabetes mellitus tidak perlu melakukan suntik insulin dalam pengobatannya tetapi menggunakan obat yang bisa memperbaiki fungsi insulin dengan baik dan menurunkan kadar gula darah akibat kerja pankreas yang kurang baik tadi (Tandra, 2015).

Peningkatan penderita DM di Indonesia terjadi dari 6,9\% pada tahun 2013 menjai 8,5 \% pada tahun 2018 menurut konsensus perkeni 2011, sedangkan menurut konsensus perkeni pada tahun 2015 yaitu 10,9\% (Rikesdas, 2018). Ada beberapa penatalaksanaan diabetes mellitus diantaranya adalah edukasi, aktivitas fisik, pengobatan, pengelolaan diet. Penyakit DM merupakan penyakit yang berhubungan dengan gaya hidup, sehingga dari kebiasaan pola makan penderita DM cenderung terus menerus mengonsumsi makanan yang tinggi akan karbohidrat dan makanan sumber glukosa secara berlebihan, sehingga dapat menaikkan kadar glukosa darah, maka dari itu perlu adanya pengelolaan diet bagi pasien DM dalam menjaga kadar glukosa darahya agar tetap terkendali (Indirawati, 2012).

Menurut Sackett (1976 dalam Niven 2013) mendefinisikan kepatuhan pasien sebagai sejauhmana perilaku pasien sesuai dengan dengan ketentuan yang diberikan oleh profesional kesehatan. Sebagian dari penderita diabetes mellitus mengetahui pentingnya diet tersebut, akan tetapi ada beberapa yang masih tidak patuh dalam menjalankan dietnya. Baik itu disengaja ataupun tidak disengaja. Berbagai alasan penderita tidak memematuhi apa yang telah dianjurkan oleh tenaga kesehatan dalam menjalankan dietnya diantaranya adalah rasa bosan.

Kepatuhan diet DM dapat dipengaruhi oleh dua faktor yaitu faktor internal dan faktor eksternal. Faktor internal yang dapat mempengruhi kepatuhan diet seperti pendididkan, 
pengetahuan, keyakinan dan sifat kepribadian. Faktor eksternal meliputi interaksi profesional kesehatan dengan pasien, faktor lingkungan dan dukungan keluarga. Dukungan keluarga sangat berpengaruh bagi penderita DM terhadap kepatuhan diet. Disaat anggota keluarga mengalami masalah kesehatan anggota yang lain berperan sangat penting dalam masalah keperawatan. Maka dari itu dukungan keluarga sangat penting untuk penderita DM dalam menjalani kepatuhannya terhadap diet (Rafani \& Ben, 2012).

Dampak positif dari dukungan keluarga dalam menjalankan diet bagi penderita DM yaitu dapat mengontrol apa yang dianjurkan oleh tenaga kesehatan dalam menjalankan dietnya, dapat saling mengingatkan, serta saling memotivasi antar anggota keluarga terutama bagi keluarga yang sedang menjalankan diet sehingga penderita DM termotivasi untuk tetap menjalankan diet dan berkeinginan utuk mempertahankan atau memperbaiki kualitas hidupnya.

Kota Cimahi merupakan salah satu kota yang berada di Jawa Barat dimana DM menjadi salah satu masalah kesehatan masyarakat di Kota Cimahi. Data dari Dinas Kesehatan Kota Cimahi mengenai kasus DM adalah sebagai berikut Cimahi Tengah dengan tingkat prevalensi 1.036, Cimahi Utara 1.189, Cimahi Selatan 1.583, Melong Asih 625, Padasuka 701, Cigugur 769, Cipageran 850, Cibereum 1.027, Leuwi Gajah 898, dan Citeureup 578 (Dinkes Kota Cimahi, 2018). RW 15 di wilayah kerja Puskesmas Cimahi Utara merupakan RW dengan jumlah penderita DM terbanyak yaitu 48 orang. Banyak penelitian, salah satunya yang dilakukan Anjani (2018) menyebutkan bahwa dukungan keluarga mempengaruhi kepatuhan melalui peningkatan optimisme dan self-esteem pasien. Namun studi empiris oleh Gherman A, et all (2011) menemukan hasil sebaliknya dimana dukungan sosial juga menjadi hambatan signifikan pada kemampuan self-care pasien. Penelitian ini dilakukan dengan tujuan untuk mengetahui "Hubungan antara dukungan keluarga dengan kepatuhan diet pada penderita DM tipe 2 di RW 15 wilayah kerja Puskesmas Cimahi Utara“.

\section{METODE PENELITIAN}

Desain penelitian ini adalah descriptive correlational study. Teknik pengambilan sampel menggunakan total sampling yaitu 48 orang penderita DM tipe 2 yang tercatat di RW 15 Puskesmas Cimahi Utara. Penelitian ini dilakukan selama 3 hari. Untuk variabel dukungan keluarga menggunakan kuisioner Hensarling Diabetes Family Support Scale (HDFSS). 
Kuesioner ini terdiri dari 25 pernyataan mengenai dukungan informasi, penghargaan, emosional, dan instrumental dengan 4 pilihan jawaban. Sementara itu, kepatuhan diet diukur menggunakan kuisioner Perceived Dietary Adherence Questionare (PDAQ) terdiri dari 9 pertanyaan dengan 7 poin jawaban berskala likert yang sudah dialihbahasakan. Uji analisis yang digunakan dalam penelitian ini adalah analisis univariat dan analisis bivariat dengan menggunakan uji statistik non parametrik chi-square. Seluruh responden dalam penelitian ini mendapatkan penjelasan baik secara lisan dan tulisan. Kesediaan responden diperoleh dengan menandatangani surat persetujuan. Peneliti memastikan partisipasi responden bersifat sukarela dan menjamin kerahasiaan informasi. Dimana publikasi hasil penelitian hanya untuk kepentingan akademik.

\section{HASIL DAN PEMBAHASAN}

\section{a. Hasil Penelitian}

Tabel 1. Distribusi Frekuensi Kepatuhan Diet pada Penderita Diabetes Tipe 2 di RW 15 wilayah Kerja Puskesmas Cimahi Utara 2019 (n=48)

\begin{tabular}{llcc}
\hline No & Kepatuhan diet & Frekuensi & Persentase $(\boldsymbol{\%})$ \\
\hline 1 & Patuh & 27 & 56,3 \\
2 & Tidak patuh & 21 & 43,8 \\
\hline & Total & 48 & 100,0 \\
\hline
\end{tabular}

Berdasarkan tabel 1 di atas didapatkan hasil dari 48 responden, lebih dari setengah responden patuh terhadap diet DM dengan $27(56,3 \%)$ responden.

Tabel 2. Distribusi Frekuensi Dukungan Keluarga dalam Menjalankan Kepatuhan Diet pada Penderita Diabetes Tipe 2 di RW 15 wilayah Kerja Puskesmas Cimahi Utara 2019 $(\mathrm{n}=48)$

\begin{tabular}{cccc}
\hline No. & $\begin{array}{c}\text { Dukungan } \\
\text { keluarga }\end{array}$ & Frekuensi & $\begin{array}{c}\text { Persentase } \\
(\boldsymbol{\%})\end{array}$ \\
\hline 1 & Baik & 23 & 47,9 \\
2 & Buruk & 25 & 52,1 \\
\hline & Total & 48 & 100,0 \\
\hline
\end{tabular}

Berdasarkan tabel 2 di atas didapatkan hasil dari 48 responden kurang dari setengah responden memiliki dukungan keluarga baik yaitu 23 (47,9\%) responden. 
Tabel 3. Hasil Tabulasi Silang antara Dukungan Keluarga dengan Kepatuhan Diet pada Penderita Diabetes Tipe 2 di RW 15 wilayah Kerja Puskesmas Cimahi Utara 2019 (n=48)

Dukungan

Keluarga

\section{Kepatuhan Diet}

$\mathbf{P}$

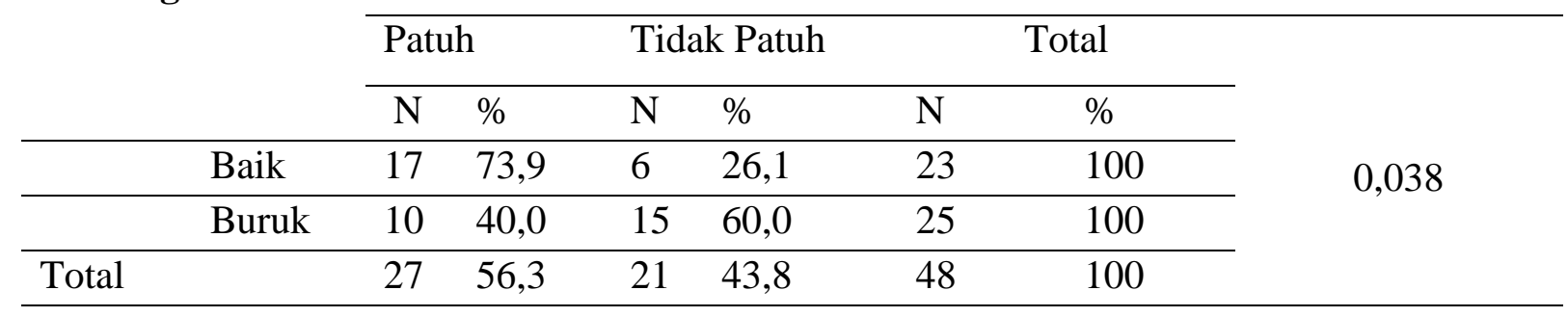

Berdasarkan tabel 3 di atas didapatkan responden yang memiliki dukungan keluarga baik, patuh dalam menjalankan diet DM sebanyak 17 (73,9\%) responden dari 23 responden. Sedangkan sebanyak $15(60,0 \%)$ responden dengan dukungan keluarga buruk memiliki ketidakpatuhan dalam menjalankan diet DM. Berdasarkan hasil uji statistik didapatkan $\mathrm{p}=0,038(\mathrm{p} \leq 0,005)$ berarti Ho ditolak, maka terdapat hubungan antara dukungan keluarga dengan kepatuhan diet pada penderita diabetes mellitus tipe 2 di RW wilayah kerja Puskesmas Cimahi Utara.

\section{b. Pembahasan}

1. Gambaran Kepatuhan Diet Pasien Diabetes Mellitus Tipe 2

Berdasarkan tabel 1 diketahui 56,3\% responden patuh dalam menjalankan diet. Hasil ini diperoleh karena sebagian besar responden mengaku sudah mendapatkan penyuluhan dari puskesmas sehingga cukup paham mengenai diet DM. Selain itu, salah satu responden mengatakan bahwa ia selalu diawasi oleh anaknya untuk menjalankan diet DM sesuai rekomendasi dari perawat dan dokter di Puskesmas. Hal ini sejalan dengan yang penelitian yang dilakukan oleh Yulia (2015) bahwa dukungan keluarga menjadi salah satu faktor yang mempengaruhi diet. Temuan di lapangan juga diketahui bahwa responden khawatir dengan komplikasi yang akan dideritanya jika dia tidak mematuhi diet yang sudah dianjurkan. Tombokan (dalam Yulia, 2015) mengatakan dalam konteks perubahan pola makan bagi penderita DM, perubahan didasarkan pada keinginan responden untuk sembuh dan mengurangi kecacatan seperti kerusakan pada mata yang dialami sebagian responden akibat menderita DM sehingga mereka termotivasi untuk mengikuti program diet yang dianjurkan oleh dokter. 
Menurut (Almatsier, 2010) bahan makanan yang dianjurkan untuk diet diabetes melitus adalah sumber karbohidrat kompleks, seperti nasi, roti, mi, kentang singkong, ubi dan sagu, sumber protein rendah lemak, seperti ikan, ayam tanpa kulit, susu krim, tempe, tahu, dan kacang-kacangan, sumber lemak dalam jumlah terbatas yaitu bentuk makanan yang mudah dicerna. Makanan terutama diolah dengan cara dipanggang, dikukus, disetup, direbus, dan dibakar. Berdasarkan hasil penelitian, sebagian responden telah mengonsumsi makan buah dan sayur setiap hari. Namun juga masih mengkonsumsi kopi, teh manis, dan gorengan ataupun makanan yang mengandung banyak lemak dan dengan jadwal makan yang tidak teratur. Responden beralasan hal ini disebabkan karena semakin hari nafsu makan semakin menurun, responden mengira hal ini dikarenakan faktor umur. Begitupun dengan jenis makanan /minuman yang dikonsumsi oleh responden juga makanan tinggi gula hal ini dikarenakan sudah menjadi kebiasaannya setiap hari sehingga jika terlewatkan akan merasakan rasa yang tidak enak badan, seperti pusing.

Dari hasil penelitian juga diketahui bahwa akibat durasi menderita DM sudah lebih dari 5 tahun maka responden bosan dalam menjalankan diet. Situasi ini sesuai dengan pernyataan Walker (dalan Rodhianto, 2013) bahwa semakin lama waktu sakit akan meningkatkan waktu penerimaan pasien terhadap penyakitnya sehingga hal tersebut akan mempengaruhi banyaknya informasi yang didapat pasien terhadap penatalaksanaan diabetes mellitus termasuk penatalaksanaan pengelolaan diet yang harus dijalankannya.

\section{Gambaran Dukungan Keluarga Pasien Diabetes Mellitus Tipe 2}

Hasil analisis yang didapatkan pada tabel 2 menunjukkan bahwa kurang dari setengah responden $(47,9 \%)$ memiliki dukungan keluarga yang baik. Dukungan keluarga adalah bantuan yang diberikan oleh anggota keluarga yang dapat memberikan kenyamanan fisik dan psikologis pada individu yang sedang menghadapi situasi stress. (Taylor, 2006). Proses dukungan keluarga terjadi sepanjang masa kehidupan, dengan sifat dan tipe dukungan yang bervariasi dalam tiap tahap siklus kehidupan keluarga. Menurut (Friedman, 2010) dalam setiap tahap siklus kehidupan, dukungan keluarga mendorong keluarga untuk berfungsi optimal dan meningkatkan adaptasi terhadap kesehatan keluarga. 
Sarafirno (2011) menyatakan bahwa dukungan keluarga terdiri dari 4 dimensi yaitu dukungan emosional, dukungan informasi, dukungan instrumental dan dukungan penghargaan. Maka dengan adanya terpenuhinya 4 dimensi tersebut maka responden yang memiliki dukungan keluarga baik cenderung untuk lebih patuh dalam menjalankan diet DM. Pada penelitian yang telah dilakukan didapatkan hasil kurang dari sebagian responden memiliki dukungan keluarga yang baik. Hal ini disebabkan oleh anggota keluarga yang sibuk dengan pekerjaannya, dimana mayoritas anggota keluarga responden bekerja menjadi asisten rumah tangga di perumahan dekat pemukiman responden. Ada pula responden yang mengatakan keluarga menyerahkan semuanya kepada responden, tidak memaksakan responden untuk melakukan diet DM dengan alasan adanya rasa kasihan terhadap responden yang telah menjalakan diet DM selama bertahun tahun sehingga responden bosan untuk melakukannya kembali dan alasan yang lain yaitu karena responden susah untuk diberikan saran, nasihat atau masukan.

Dari hasil penelitian, diketahui bahwa dukungan keluarga yang sering diberikan oleh keluarga kepada responden yaitu dukungan keluarga emosional. Dukungan keluarga emosional, yang melibatkan ekspresi empati-,perhatian, pemberian semangat, kehangatan pribadi, cinta atau bantuan emosional. Dengan adanya dorongan tingkah laku yang mendorong perasaan nyaman dan mengarahkan responden bahwa ia dipuji, dihormati, dicintai dan orang lain bersedia untuk memberikan perhatian (Friedman, 2010).

Dukungan emosional yang diberikan keluarga kepada responden dapat meningkatkan pemulihan dan moral keluarga. Dengan adanya dukungan keluarga emosional yang diberikan oleh keluarga, responden merasa diperhatikan dan dimengerti oleh keluarganya. Dukungan lain yang dilakukan adalah membantu mengatasi kecemasan responden yang disebabkan oleh DM yang ia derita. Dari hasil penelitian diketahui bahwa jika kadar gula darah responden sedang meningkat, keluarga membantu menenangkan agar tidak semakin cemas serta mengingatkan waktu control ke posbindu hingga mengingatkan tentang diet.

Berdasarkan temuan tersebut, peneliti menyimpulkan dari hal kecil seperti memberikan semangat, perhatian atau memahami kondisi saat responden sedang mengalami masalah yang berhubungan dengan penyakit DM-nya dapat berdampak positif untuk kesehatan responden. Sebagaimana dikemukakan oleh Huang, et al (2014) bahwa dukungan keluarga dapat meningkatkan persistensi perilaku self-management. 
Dukungan berupa materi dan spiritual dapat mengurangi stress psikologis, meredekan ketegangan, meningkatkan adaptasi social, dan pasien lebih termotivasi untuk melawan penyakit. Pada pasien DM, partisipasi anggota keluarga dalam diet khususnya berkontribusi terhadap keberhasilan penatalaksanaan DM.

Dampak positif yang lain bisa ditimbulkan oleh dukungan keluarga yang diberikan adalah dengan pemberian informasi. Temuan dari penelitian ini menunjukan keluarga memberikan saran untuk mengikuti kegiatan posbindu, melakukan pemeriksaaan kedokter, serta ada beberapa anggota keluarga responden yang menjadi kader posbindu, sehingga dapat informasi mengenai penatalaksanaan DM dari Prolanis bisa tersampaikan. Friedman (2010) mengatakan bahwa dukungan informasi merupakan dukungan yang diberikan dengan cara memberi nasihat, saran, dan diskusi tentang bagaimana cara atau memecahkan masalah yang ada.

Selain itu ada juga dukungan instrumental, yang merupakan dukungan konkrit dan praktis (Friedman, 2010). Dalam penelitian ini dukungan instrumental yang diberikan oleh kebanyakan keluarga responden yaitu dengan cara membantu dalam membayar pengobatan responden. Meskipun masih ada keluarga responden yang tidak membantu responden dalam membayar pengobatan dikarenakan responden menolak dan mengatakan bisa untuk membayar pengobatan sendiri.

3. Hubungan antara Dukungan Keluarga dengan Kepatuhan Diet pada Pasien Diabetes Mellitus Tipe 2

Berdasarkan tabel 3 menunjukkan bahwa terdapat hubungan yang signifikan antara dukungan keluarga dengan kepatuhan diet dengan $p$ value sebesar 0,038. Hal ini dikarnakan apabila dukungan keluarga baik makan kepatuhan diet pun akan baik, dan sebaliknya jika dukungan keluarga buruk kepatuhan dietpun akan buruk. Hasil penelitian ini sejalan dengan penelitian yang dilakukan oleh (Arifin, 2015) yang menunjukan adanya hubungan antara dukungan keluarga dengan kepatuhan diet diabetes mellitus tipe 2 di di poliklinik penyakit dalam RSUP Dr, Soeradji Tirtonegoro Klaten.

Anggina (2010) menyampaikan bahwa dukungan keluarga yang adekuat terbukti berhubungan dengan menurunnya mortalitas, lebih mudah sembuh dari sakit, fungsi kognitif dan kesehatan emosi. Dilihat dari penelitian yang sudah dilakukan oleh peneliti sebagian responden sudah mengalami komplikasi sehingga keluarga sangat 
memperhatikan kesehatan responden terutama mengenai kepatuhan diet diabetes mellitus yang dijalankan oleh responden sehingga responden patuh menjalankan dietnya dan merasa diperhatikan oleh keluarga responden sendiri..

Responden yang memiliki dukungan keluarga yang baik maka kepatuhan dietnya cenderung baik. Hal ini disebabkan karena adanya motivasi dari keluarga yang membuat responden merasa dihargai, diperhatikan, diperdulikan dicintai dan mempunyai rasa percaya diri untuk sembuh. Begitu pula sebaliknya, jika dukungan keluarga rendah maka responden tidak mempunyai motivasi untuk sembuh dan tidak ada keinginan untuk memperbaiki kesehatannya. Hal tersebut sesuai dengan pendapat Efendi (2009), bahwa dukungan keluarga sangat berperan terhadap kepatuhan yaitu pada penderita yang didukung oleh keluarga akan memiliki percaya diri dan motivasi untuk sembuh. Seseorang dengan dukungan keluarga yang tinggi memungkinkan lebih berhasil menghadapi dan menjalankan program diet dibanding yang tidak memiliki dukungan.

Seiring berjalannya waktu, keluarga adalah sumber utama pasien DM dalam melaksanakan self-management di rumah. Salah satu fungsi keluarga menurut Fiedman (2010) adalah perawatan keluarga, kemampuan keluarga melakukan asuhan keperawatan atau pemeliharaan kesehatan memengaruhi status kesehatan keluarga dan individu. Apapun jenis penyakit kronik yang diderita, keluarga ditantang untuk membantu anggota keluarga untuk tetap sehat, mencegah komplikasi, dan untuk mengelola komplikasi, memasukan perubahan fisik dan status mental dalam peran fungsi keluarga, dan untuk mengelola komplikasi atau kecacatan (Kaakinen, Hanson, \& Denham, 2010).

\section{KESIMPULAN}

Berdasarkan hasil penelitian dan pembahasan diatas, maka dapat ditarik kesimpulan ada hubungan yang signifikan antara dukungan keluarga dengan kepatuhan diet pada penderita diabetes mellitus tipe 2 di RW 15 wilayah kerja Puskesmas Cimahi Utara dengan p=0,038. Bagi keluarga diharapkan lebih terlibat dalam penatalaksanaan DM terutama memperhatikan, mengawasi, dan menyiapkan diet bagi anggota keluarganya yang menderita DM. Bagi peneliti selanjutnya diharapkan dapat melakukan penelitian dengan mengeksplorasi metoda maupun intervensi untuk memfasilitasi dukungan keluarga pada pasien DM. 
Jurnal Ilmu Keperawatan Medikal Bedah 3 (1), Mei 2020, 1-76

ISSN 2338-2058 (print), ISSN 2621-2986 (online)

\section{DAFTAR PUSTAKA}

Almatsier, S. (2010). Penuntun diet. Jakarta: Gramedia.

Arifin. (2015). Hubungan dukungan keluarga dengan kepatuhan diet diabetes mellitus tipe 2 di dipoliklinik penyakit dalam RSUP Dr, Soeradji Tirtonegoro Klaten. Jurnal Nursing.

Budiman. (2011). Penelitian kesehatan. Jakarta: EGC.

Dahlan, S. M. (2010). Besar sampel dan cara pengambilan sampel dalam penelitian kedokteran dan kesehatan. Edisi 3. Jakarta: Salemba Medika.

Dharma, K. K. (2011). Metodologi penelitian keperawatan. Jakarta: Trans info media.

Efendi, Makhfudli. (2009). Keperawatan kesehatan komunitas teori dan praktik dalam keperawatan. Jakarta: Salemba Medika.

Fransisca, K. (2012). Awas pankreas rusak penyebab diabetes. Jakarta: Cerdas Sehat.

Friedman, M. M. (2010). Buku ajar keperawatan keluarga : riset, teori, \& praktik. Jakarta: EGC.

Garnadi, Y. (2012). Hidup nyaman dengan diabetes. Jakarta: PT. Argo Media Pustaka.

Gherman, A., Schnur, J., Montgomery, G., Sassu, R., Veresiu, I., David, D. (2011). How are adherent people more likely to think? A meta-analysis of health beliefs and diabetes self-care. Diabetes Educ.

Hisni, D. (2017). Hubungan dukungan keluarga dengan kepatuhan diet diabetes mellitus pada pasien DM tipe 2 di Wilayah Puskesmas Limo Depok. Jurnal Keperawatan dan Kebidanan Nasional.

Hurst, M. (2015). Belajar mudah keperawatan medikal-bedah, Vol. 2. Jakarta: Buku Kedokteran EGC.

Indirawati. (2012). Hubungan motivasi denagn kepatuhan diet diabetes mellitus di Desa Tagkil Wilayah Kerja Puskesmas Kedungwuni di Kabupaten Pekalongan.

LeMone, P. (2012). Buku ajar keperawatan medikal bedah. Ed.5. Vol.2. Jakarta : Buku Kedokteran EGC.

Kaakinen, J.R., Hanon, S.H., \& Denham, S.A. (2010). Family health care nursing, theory practice and research (4th Ed., Chapter 1). Davis Company, Philadelphia.

Narbuku, C., \& Achmadi, a. (2015). Metodologi penelitian. Jakarta: PT Bumi Aksara.

Niven, N. (2013). Psikologi kesehatan pengantar untuk perawat dan profesi lainnya. Jakarta: EGC.

Notoatmodjo, S. (2014). Metodologi penelitian kesehatan. Jakarta: Rineka Cipta.

Notoatmodjo, S. (2018). Metodologi penelitian kesehatan. Jakarta: Rineka Cipta. 
Padila. (2012). Buku ajar keperawatan medikal bedah. Yogyakarta: Nuha Medika.

Prihaningtyas, R. A. (2013). Hidup manis dengan diabetes. Yogyakarta: Media Pressindo.

Rafani, \& Ben. (2012). Panduan pola makan sehat dan cerdas bagi penderita diabetes. Denpasar: Bumi Aksara.

Salam, A. Y. (2017). Efek self efficacy training terhadap self efficacy dan kepatuhan diet diabetesi. E-Journal Undip.

Smeltzer, S. C. (2012). Keperawatan medikal bedah. Edisi 12. Jakarta: Buku Kedokteran EGC.

Sugiyono. (2011). Metode penelitian kuantitatif, kualitatif. Bandung: Alfabeta.

Supariasa, D. N., Bakti, B., \& Fajar, I. (2014). Penilaian status gizi. Ed. 2. Jakarta: EGC.

Susilowati \& Kuspriyanto. (2016). Gizi dalam daur kehidupan. Bandung: PT. Refika Aditama.

Tandra, H. (2015). Diabetes bisa sembuh petunjuk praktik mengalahkan dan menyembuhkan diabetes. Jakarta: Gramedia Pustaka Utama.

Taylor, S.E. (2006). Health psychology (6th Ed.). Singapore: MC. Grow Hill Book Company.

Widyanto. (2013). Trend Disease " Trend penyakit saat ini ". Jakarta: CV trans info media.

Winahyu, K. (2018). kepatuhan diet klien diabetes mellitus tipe 2 ditinjau dari dukungan keluarga di puskesmas cipondoh tangerang. Jurnal ilmiah keperawatan indonesia.

Yasmara, D., Nursiswati, \& Arafat, R. (2016). Rencana Asuhan Keperawatan Medikal Bedah: Diagnosis NANDA-I 2015-2017 intervensi NIC hasil NOC. Jakarta: EGC. 